\title{
Effects of wave action on nesting activity in the littoral five-spotted wrasse, Symphodus roissali (Labridae), in the northwestern Mediterranean Sea*
}

\author{
NURIA RAVENTOS \\ Centro de Estudios Avanzados de Blanes (CSIC), carrer d'accés a la Cala Sant Francesc, 14, 17300 Blanes, Girona, \\ Spain. E-mail: nuria@ceab.csic.es
}

\begin{abstract}
SUMMARY: The nesting activity of the littoral five-spotted wrasse, Symphodus roissali, was investigated near Blanes (northwestern Mediterranean Sea). Males construct and defend several nests over the entire reproductive period while females spawn asynchronously in these nests. Nesting activity continued from around the end of March to the end of June in the case of the study population. Nesting intensity, nesting success and nest destruction varied between years and sites. Differences between the numbers of nests that survive the nesting cycle and those that are destroyed can be related to environmental conditions, primarily wave height. Sufficiently protracted periods ( $>1$ week) of favourable sea conditions allow nests to survive and complete their cycle.
\end{abstract}

Key words: labrid fishes, wave action, nesting success, nest destruction, Mediterranean Sea.

RESUMEN: El EFECTO DEL OLEAJE SOBRE LA ACTIVIDAD NIDIFICADORA DEL LÁBRIDO DE LITORAL PLANCHITA SYMPHODUS ROISSALI (LABRIDAE), EN El MEditerRáneo Noroccidental. - La actividad nidificadora del lábrido de litoral Planchita, Symphodus roissali, fue investigada cerca de Blanes, en el Mediterráneo Noroccidental. Los machos construyen y defienden varios nidos a lo largo del período reproductor en los cuales las hembras ponen sus huevos. La actividad nidificadora se extiende desde cerca de finales de Marzo hasta finales de Junio para la población objeto de estudio. La intensidad nidificadora, el éxito nidificador y la destrucción de nidos varió entre años y entre estaciones de muestreo. Las diferencias en el número de nidos que sobreviven con los que son destruidos pueden ser relacionadas con las condiciones ambientales, principalmente con la altura de ola. Períodos de tiempo suficientemente largos (>1 semana) con condiciones de mar favorables permiten que los nidos sobrevivan y completen sus ciclos.

Palabras clave: lábridos, efecto del oleaje, éxito nidificador, destrucción de nidos, Mar Mediterráneo.

\section{INTRODUCTION}

The timing of reproduction in marine fishes shows considerable variation at different temporal scales (i.e. daily, seasonally) and numerous hypotheses have been proposed to explain the advantages of the different time scales with respect to spawning activity. Most of these hypotheses have concentrat-

*Received May 13, 2003. Accepted October 17, 2003. ed on the relationship between larval biology and environmental conditions that can improve larval survival and recruitment (Cushing, 1969; Johannes, 1978; Walsh, 1987; Robertson, 1991). However, several authors have suggested that these larval biology hypotheses cannot explain much of the observed variation in the timing of reproduction (Robertson et al., 1990; Robertson, 1991; Secor, 2000), and that explanations based on adult biology should also be included (see also Goulet 1995). 
In temperate areas, the presence of a restricted period of benign conditions usually produces sharply defined spawning seasons (Ebeling and Hixon, 1991; Robertson, 1991). At a regional scale, weather conditions can act as determinant of spawning periodicity (Goulet, 1995). The study of population dynamics of littoral fishes under different weather conditions affords a good opportunity to assess the relative importance of environmental stress as a determinant of seasonal patterns of spawning. For nesting fishes inhabiting shallow littoral areas, weather conditions-reflected mainly in wave action - can adversely affect not only the survival of larvae and recruits but also reproduction itself by preventing nesting activity.

Several studies have attempted to relate environmental parameters, mostly rainfall and its effects on current velocity and flooding, and the nesting activities of freshwater fishes (Noltie and Keenleyside, 1987; Jennings and Philipp, 1994; Lucas and Orth, 1995; Mol, 1996). However, there are a few studies that relate wave action with nesting success in lakes (Goff 1985, 1986; Nack et al., 1993; Popiel et al., 1996), and no studies on the direct effects of wave action on nest viability in marine nesting fishes.

The five-spotted wrasse, Symphodus roissali, is a common nesting fish in the shallow waters of the Mediterranean Sea. This genus has previously been well documented in terms of its mating system (Lejeune and Voss, 1979a, b, 1980; Helas et al., 1982; Lejeune, 1985), and particularly aspects of its nesting behaviour (Lejeune, 1985), parental care (Warner and Lejeune, 1985; van den Berghe, 1990) and mate choice (Wernereus et al., 1987). Although these studies have provided insightful information about social aspects of nesting behaviour, there is still a lack of studies of the overall reproductive period, including the influence of environmental factors on nesting activity.

The objective of the present study was thus to establish, over a three-year period, possible interannual fluctuations in certain primary features of spawning, namely: (a) nesting intensity (measured as the number of nest-building starts), (b) nesting success (measured as the number of nests surviving all stages of the nesting cycle), and (c) nest destruction (measured as the number of nests that were washed away and destroyed during this cycle). Variations in such attributes in relation to weather conditions (mainly wave height) were then also examined.

\section{MATERIALS AND METHODS}

\section{Study species}

The five-spotted wrasse, Symphodus roissali, is a small $(\mathrm{TL}<15 \mathrm{~cm})$, endemic Mediterranean labrid inhabiting shallow areas of the littoral zone $(<6 \mathrm{~m}$ depth) (Quignard and Pras, 1986). It dwells on shallow rocky bottoms with abundant algal cover (Helas et al., 1982). The oldest individuals recorded have been less than three years old (Gordoa et al., 2000), and the natural mortality rate appears to be high (Macpherson et al., 2000). Spawning takes place between April and June, and the appearance of the first new settlers is observed in May (Quignard and Pras, 1986; García-Rubies and Macpherson, 1995; and personal observations). There is no lunar relationship with nesting behaviour. (Lejeune, 1985; Helas et al., 1982). The entire nesting cycle of the male (consisting of nest building, accepting females, guarding and fanning the eggs) takes between one and two weeks, depending on water temperature (Lejeune, 1985; and personal observation). Larval stage duration is quite short, on average less than 14 days (Raventós and Macpherson, 2001). The sex ratio for this species is 1:1 (Lejeune, 1985). This dichromatic species displays two non-permanent colour patterns that can be clearly observed during the spawning period (Warner and Lejeune, 1985). Terminal-phase (brightly coloured) males build nests that are visited by females. Initial-phase (duller coloured) males do not build nests and are thus compelled to fertilise eggs by sneaking.

\section{Study site}

The study was carried out off the coast of Catalonia in northeastern Spain (NW Mediterranean

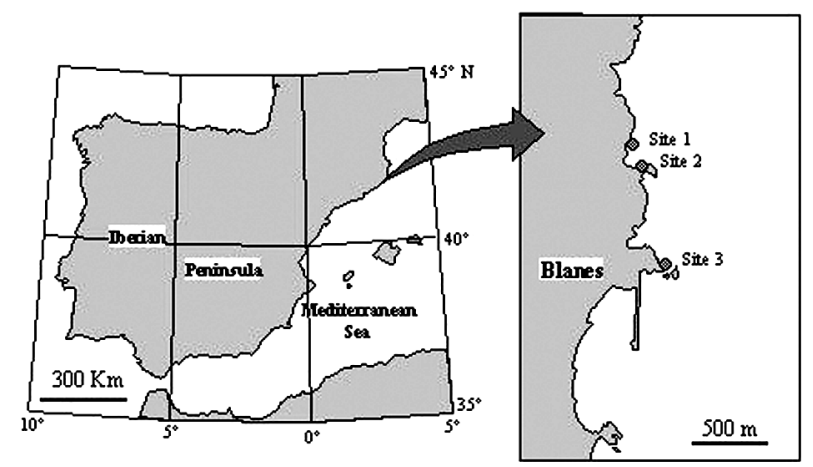

FIG. 1. - Map of the coast of Catalonia, Spain, showing the locations of the sampling sites near Blanes (Sites 1, 2, and 3). 
Sea) (Fig. 1) from March to July in 1998, 1999 and 2000. Three study sites were sampled. The first two sampling stations were located at the northernmost (Site 1) and southernmost (Site 2) ends of the same bay, separated by a long sandy beach. The third sampling station (Site 3) was relatively isolated from the coastline, being located at the end of a small isthmus. The characteristics of all three sites were similar, and natural barriers (e.g. the presence of broad sandy strips) were presumed to ensure separation of the three subpopulations considered. Accordingly, the adult population at each site was regarded as a separate spawning stock.

The three sampling sites were similar in size, $200 \mathrm{~m}^{2}$, and all consisted of a shallow (0-6 m depth) habitat comprising an entirely rocky bottom with abundant algal cover.

\section{Wave height measurement}

Significant wave heights (defined as the mean one third of the highest amplitudes recorded) were obtained from a surface wave buoy (WANA Buoy) located at a distance of $15 \mathrm{~km}$ off-shore from the study sites. Data were recorded every three hours, and later averaged over a $24 \mathrm{~h}$ period. In a previous study, Zika (1999) has shown that cross-correlations between daily averaged wave heights for a buoy located further away $(30 \mathrm{~km})$ and another buoy located just $3 \mathrm{~km}$ distant from the study sites indicated highly correlated wave events for the two locations ( $r>0.75$ for the years 1996 and 1997, 0 day lag time). Based on these results, the data from the above-mentioned buoy, located $15 \mathrm{~km}$ from the study sites, were used in this study.

\section{Nest censuses}

Surveys were conducted by SCUBA diving at each site at the beginning of March in each of the three years, before any nests had been built, in order to be able to accurately time the start of building of the first nest. From that time on, each site was visited twice weekly. The surveys were performed along a $2 \mathrm{~m}$ wide $\mathrm{x} 100 \mathrm{~m}$ long transect that traversed the entire sampling site $\left(200 \mathrm{~m}^{2}\right)$. Traversal of the survey transect took from 30 to 90 min, depending on the stage of the spawning cycle, and hence the number of nests present at each site. The total time to complete these surveys during the three-year study period was around 120 SCUBA diving hours.
Each site was mapped and overlaid with a grid to enable accurate record-keeping of all nest sightings. The maps were attached to a clip-board for census data recording during the survey dives. Nests observed were designated by the grid block number on the corresponding site map; the block surface area was $2 \mathrm{~m}^{2}$ of substratum and consequently certain blocks sometimes contained two or more nests, in which case a subscript was added to the individual nest designations for identification purposes.

Nests were classified according to one of the three stages of the spawning cycle as described by Lejeune (1984): stage 1) nest-building ( $2.4 \pm 0.8$ days); stage 2) sexual activity ( $2.4 \pm 0.8$ days); and stage 3 ) fanning (ventilation) (10.6 \pm 2.5 days). On this basis, the time 0 , or beginning of stage 1 , for stage 2 or stage 3 nest sightings, was back-calculated with an acceptable degree of accuracy. Accordingly, for each day of the spawning period the presence or absence of nests in stage 1 was recorded. Three more categories or stages were defined for the final development of each nest: stage $S$ for successful nests that had survived and passed through stage 3 and reached the end of the nesting cycle; stage D for destroyed nests; and stage A for abandoned nests. These latter nests can be distinguished from the destroyed ones because they received no paternal care even though the nest structure was complete or only partially destroyed.

\section{Experimental design}

\section{Linkage of wave action with nesting starts and final development of the nests}

Differences in mean wave height affecting nesting starts and final development of nests were assessed using one-way ANOVA. For each day of sampling the mean value of wave height of both the day before and the same day of the sampling was compared between days with presences/absences of nesting starts (stage 1 nests, $n=$ sampling days). To determine whether sea conditions determine the final stage of each nest, means of wave height during the nesting survey period for the total number of nests reaching any of the final stages (stages, S, D or A) were compared ( $n=$ total number of nests). Moreover, to determine whether the occurrence of storms determine the final nest development (nest in stage $\mathrm{S}, \mathrm{D}$ or A), maximum values of significant wave height occurring since the last survey day were compared to the final development of each nest ( $n=$ total number of nests). 
TABLE 1. - Numbers of nest-building starts, nests surviving the entire cycle, nests destroyed and nests abandoned (percentages in brackets).

\begin{tabular}{llcccr}
\hline Year & Site & Nest starts & Surviving nests $(\%)$ & Destroyed nests (\%) & Abandoned nests (\%) \\
\hline \multirow{4}{*}{1998} & Site 1 & 28 & $10(35.7)$ & $7(25.0)$ & $11(60.7)$ \\
& Site 2 & 25 & $11(44.0)$ & $2(8.0)$ & $12(48.0)$ \\
& Site 3 & 6 & $1(16.7)$ & $1(16.6)$ & $4(66.6)$ \\
1999 & Site 1 & 80 & $23(28.7)$ & $22(27.5)$ & $35(43.8)$ \\
& Site 2 & 73 & $31(42.5)$ & $13(17.8)$ & $29(39.7)$ \\
& Site 3 & 59 & $14(23.7)$ & $24(34.3)$ & $35(49.2)$ \\
2000 & Site 1 & 70 & $34(37.0)$ & $27(29.3)$ & $31(33.7)$ \\
& Site 2 & 92 & $5(18.5)$ & $9(33.3)$ & $13(48.1)$ \\
\hline
\end{tabular}

\section{Interannual variation}

The nesting features assessed were:

a) Nesting intensity: the total number of nest building starts (stage 1 nests).

b) Nesting success: the number of nests that successfully survived all stages through to hatching of the eggs (stage $S$ nests).

c) Nest destruction: the number of nests that were completely washed away (stage D nests).

Possible inter and intra-annual differences in the features of spawning considered (nesting intensity, nesting success and nest destruction) were assessed by means of chi-square analysis.

Statistical significance of differences in wave height between years was determined by comparing mean weekly values between years using two-way ANOVA (week x year).

\section{Data processing}

Prior to analysis, some variables were transformed to normalise the data whenever necessary. In all the statistical analyses, the assumptions of normality (Kolmogorov-Smirnov test) and heteroscedascity (Cochran test) were tested before applying parametric analyses. If significant differences were detected, a posteriori comparisons were conducted using the Tukey HSD test. Differences were considered significant at $\mathrm{p}<0.05$.

\section{RESULTS}

\section{Nest censuses}

During the study a total of 1,153 observations were made on 460 nests in all. On a yearly basis, 59 nests were observed in 1998, 212 in 1999, and 189 in 2000 (Table 1). The onset of the nesting period coincided with the last week of March/first week of April and lasted until the end of June. The sampling method proved to be effective, since $95 \%$ of the nests were first spotted in stages 1 or 2 (nest-building or sexual activity stage). Building starts for the remaining $5 \%$ of nests that were not discovered in these initial stages were back-calculated to the proper week using time estimates for the nesting pattern (described in the Materials and Methods section).

The number of nests that successfully survived the entire breeding cycle was in all cases relatively low: only $30 \%$ of the 460 nest-building starts over the three years were successful (range: 15-44\%) (Table 1). The number of nests that were initiated, and after a short period abandoned, represents almost half of the total (48.9\%, range: 33.7-66.6) (Table 1).

\section{Linkage of wave height with the number of nest- ing starts and the final development of the nests}

The mean value of wave height for both the day before and the same day of the sampling did not determine the nest-building starts (presence/absence of nesting starts) (ANOVA, $p>0.05$, Fig. 2). Mean wave heights observed during the nest survey period

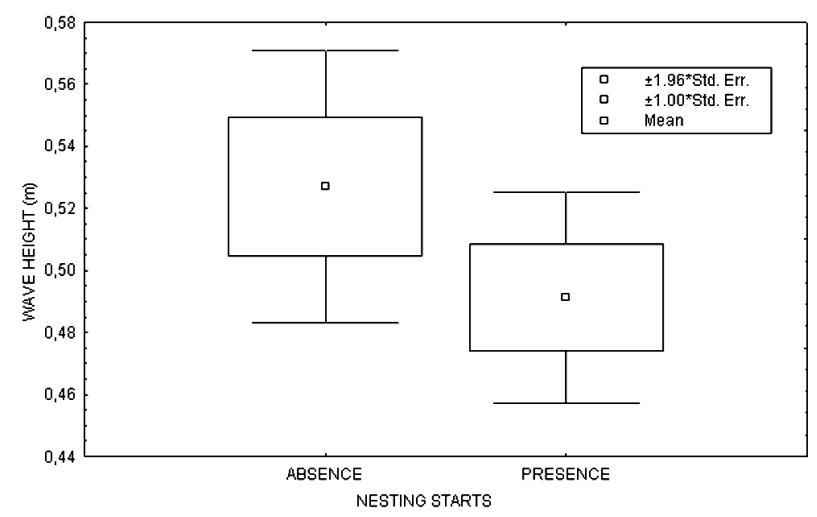

FIG. 2. - Plot of means and standard errors of wave height on both the day before and the same day of the sampling, compared for days with presence/absence of nesting starts (stage 1 nests, $n=$ sampling days). 


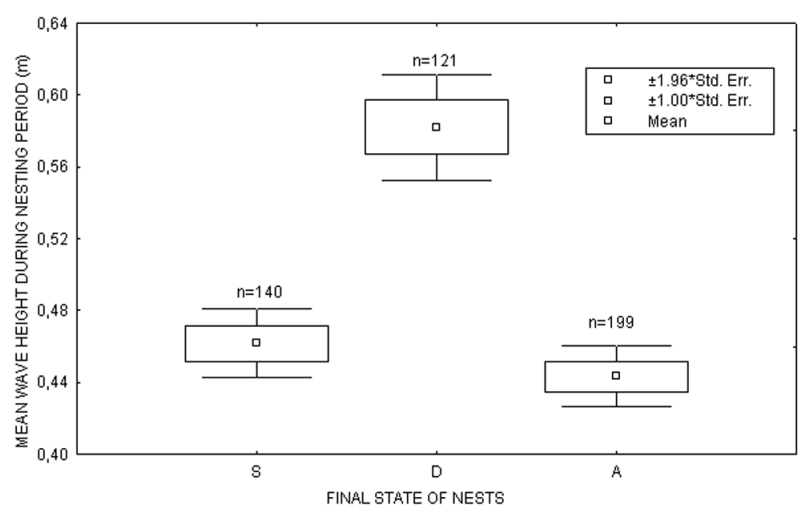

Fig. 3. - Plot of means and standard errors of wave height during the nesting survey period for the total number of nests reaching any of the final states ( $S=$ successful nests; $D=$ destroyed nest and $\mathrm{A}=\mathrm{abandoned}$ nests; $\mathrm{n}=$ total number of nests).

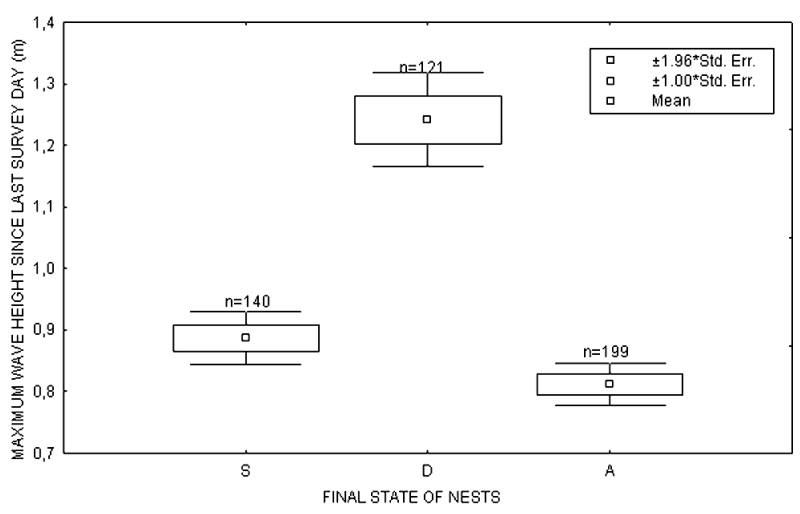

Fig. 4. - Plot of means and standard errors of maximum values of significant wave height occurring since the last survey day for the total number of nests reaching any of the final states ( $\mathrm{S}=$ successful nests; $\mathrm{D}=$ destroyed nest; $\mathrm{A}=$ abandoned nests; $\mathrm{n}=$ total number of
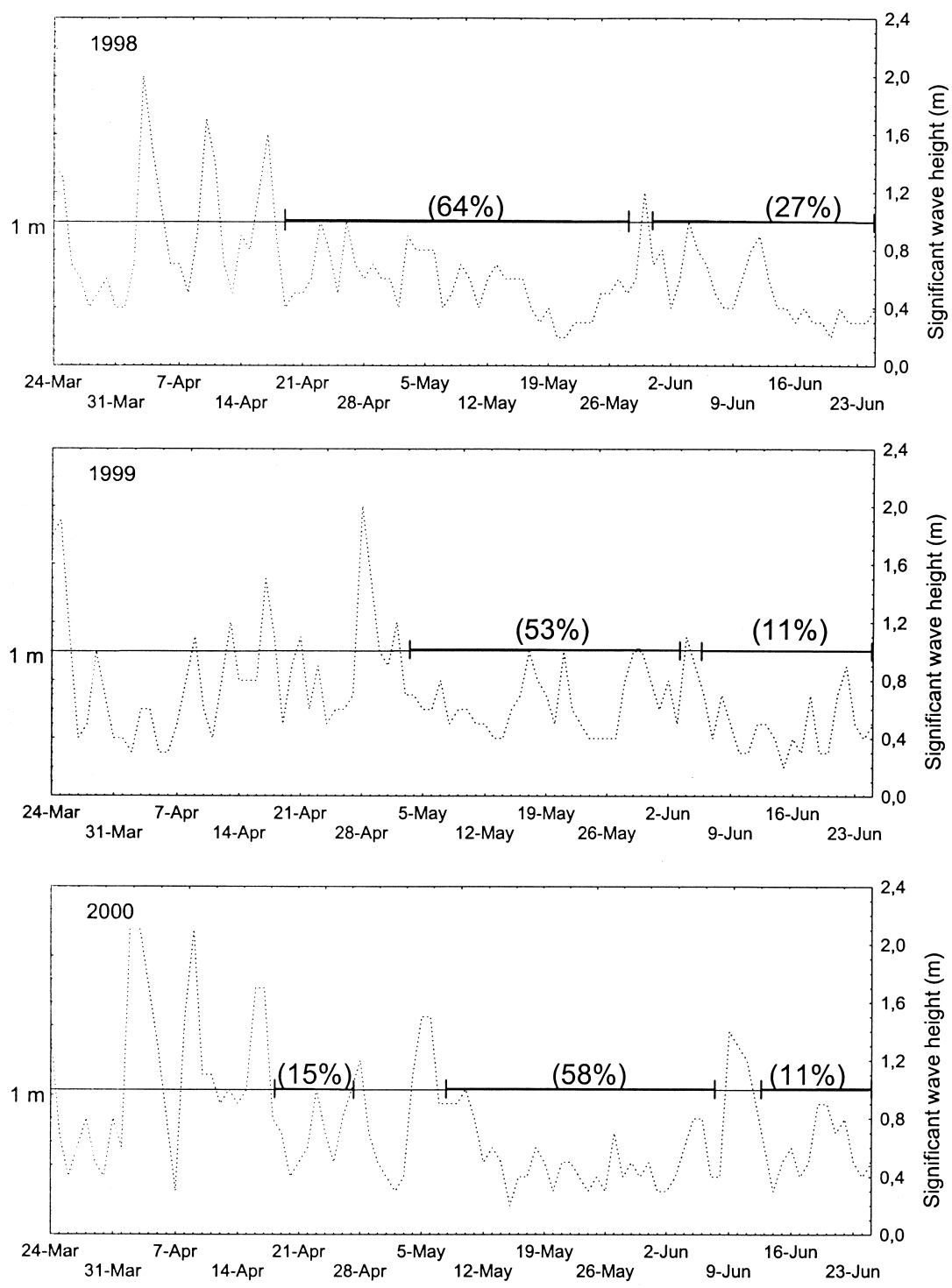

Fig. 5. - Dotted line $=$ significant wave height (mean of the highest third of measured wave heights) during the entire spawning period over the 3 years of the study. Horizontal fine line marks the level of favourable sea conditions $(<1 \mathrm{~m}$ wave height $)$. Bounded thick lines define sufficiently protracted periods ( $>1$ week) with favourable sea conditions allowing nest completion. In brackets are \% of surviving nests during such periods. 
icantly higher wave height than the successful or abandoned nests (ANOVA, $\mathrm{p}<0.05$, Fig. 3). The maximum values of significant wave height occurring since the last survey day also indicated higher maximum wave height values for nests that were destroyed rather than abandoned or successful (ANOVA, $p<0.05$, Fig. 4).

As shown above in Figure 4, wave height has a significant effect on nest destruction, being an important cause of nesting failure. On the other hand, when favourable sea conditions prevailed for at least one week, the number of nests that survived the entire nesting cycle was found to be greater than in the rest of the breeding season (Fig. 5).

\section{Interannual variation}

Mean significant wave height values during the reproduction period were $0.47 \mathrm{~m}$ in $1998(\mathrm{n}=119$; $\mathrm{SD}=0.24), 0.50 \mathrm{~m}$ in $1999(\mathrm{n}=119 ; \mathrm{SD}=0.26)$, and $0.57 \mathrm{~m}$ in $2000(\mathrm{n}=119$; $\mathrm{SD}=0.33)$. The maximum significant wave height values recorded were $1.7,2$ and $2.3 \mathrm{~m}$ respectively. These significant wave height values corresponded to estimated real maximum values of between approximately $3.3 \mathrm{~m}$ (for significant wave height values of $1.7 \mathrm{~m}$ ) and 4.5 $\mathrm{m}$ (for significant wave height values of $2.3 \mathrm{~m}$ ).

Although there was a significant interaction between weeks and years $(\mathrm{F}=2.49, \mathrm{p}<0.000)$, mean significant wave height values differed between years (ANOVA, $\mathrm{F}=5.42, \mathrm{p}=0.004$ ) and weeks (ANOVA, F = 7,93, $\mathrm{p}<0.000$ ). Post hoc analysis revealed that wave height during the year 2000 was significantly greater than in 1998 and 1999.

In 1998 there were two periods when significant wave height values were less than or equal to $1 \mathrm{~m}$, namely from 18 April to 29 May and from 1 June onwards (Fig. 5). Similar sea conditions prevailed in 1999 from 7 May to 6 June and from 5 to 25 June. In 2000 these sea conditions recurred from 7 May to 8 June and from 12 June onwards. The number of nests that survived the entire nesting cycle during these periods was higher than the values for the remainder of the spawning season $(91 \%$ in 1998 , $64 \%$ in 1999 , and $84 \%$ in 2000 ).

\section{Nesting intensity}

The number of nest-building starts during the breeding season varied both between sites (Site $2>$ Site $1>$ Site 3 ; chi-square $=7.84$ for site $2>$ site 1 , chi-square $=49.21$ for site $1>$ site 3 , chi-square $=$ 63.05 for site $2>$ site 3 , in all cases $\mathrm{df}=2, \mathrm{p}<0.05$ ) and between years (Year $1999>$ Year $2000>$ Year 1998; chi-square $=656.9$ for $1999>1998$, chi-square $=316.1$ for $2000>1998$, chi-square $=23.6$ for 1999 $>2000$, in all cases df $=2, \mathrm{p}<0.05)($ Table 1$)$.

\section{Nesting success}

The number of nests that successfully survived the entire nesting cycle during the breeding season differed between sites (Site $2>$ Site $1>$ Site 3; chisquare $=37.18$ for site $2>$ site 1 , chi-square $=11.54$ for site $1>$ site 3 , chi-square $=34.45$ for site $2>$ site 3 , in all cases $\mathrm{df}=2, \mathrm{p}<0.05$ ), and there were fewer successful nests in year 2000 than in the other two years $($ Year $2000<1999=1998$; chi-square $=12,53$ for $2000<1998$ and chi-square $=7,77$ for $2000<$ 1999 , in both cases $\mathrm{df}=2, \mathrm{p}<0.05$ ) (Table 1 ).

\section{Nest destruction}

The number of nests destroyed during the breeding season varied both between sites (Site $1>$ Site 3 $>$ Site 2 ; chi-square $=15.69$ for site $2<$ site 1 , chisquare $=2.85$ for site $1>$ site 3 , chi-square $=14.65$ for site $3>$ site 2 , in all cases $\mathrm{df}=2, \mathrm{p}<0.05$ ) and between years (Year $2000>$ Year 1999 > Year 1998; chi-square $=18.89$ for $1999>1998$, chi-square $=$ 76.97 for $2000>1998$, chi-square $=10.53$ for 2000 $>1999$, in all cases $\mathrm{df}=2, \mathrm{p}<0.05)$ (Table 1$)$.

\section{DISCUSSION}

Symphodus roissali nest sightings indicated that nesting activity in this species continued from around the end of March to the end of June for the study population in the sampling area. This seasonality corresponds with the onset of the breeding period for a large number of NW Mediterranean littoral fishes (Whitehead et al., 1986). As observed in other species (Robertson et al., 1990, Robertson, 1991, Goulet, 1995), given the restricted nesting period described here for $S$. roissali, there may be no selective advantage in displaying any lunar spawning synchrony and further confining spawning to lunar cycles. Moreover, as presented here, this restricted period can be affected to different degrees by extrinsic constraints such as enviromental stress. These factors reveal that adult biology related hypotheses, as suggested by Robertson (1991), may be more 
successful in accounting for this pattern of breeding success.

The considerable temporal (annual and interannual) and spatial variation in the number of $S$. roissali initiating nests construction (nesting intensity) and the number of nesting cycle completions (nesting success) can be related to different causes, weather conditions being the main cause determining nesting success. Nest destruction seems to depend upon sea conditions and therefore varies between years. Jennings and Philipp (1994) suggested similar results for a stream dwelling fish: during years characterised by low, relative stable flow, nest failures could be attributed to biotic interactions, and during years of more variable flow, most brood looses occurred during floods.

Mean significant wave height on both the day before and the same day of the sampling was not adequate to explain interannual and inter-site variations in the nesting intensity recorded. This may be due to the fact that the minimum period of prevailing good weather conditions necessary to trigger nest-building starts is shorter than the sampling period of this study. Although not significant, days with better sea conditions display more nesting starts than days with worse conditions. On the other hand, the percentage of nests that were able to survive the entire nesting cycle was observed to increase when prevailing sea conditions remained favourable (i.e. $<1 \mathrm{~m}$ significant wave height) for a sufficiently long time (min. 1 week), thus allowing nesting to start and proceed through all the stages in the cycle without suffering the effects of external perturbation.

Overall, the number of nests that successfully completed the entire cycle was relatively small. Of 460 nest-building starts recorded over the three-year study period, only around $15-44 \%$ succeeded in surviving the cycle (maximum and minimum value recorded). Similar low values and variability (33$88 \%$ ) of successful production of young smallmouth bass (Micropterus dolomieu) have been recorded and related to the total hours of strong winds (Goff, 1985, 1986). Differences in nesting success were significant between all sites, but not between all years. Significant differences were found for the year 2000, this being a less successful nesting year than the other two. If wave action is responsible for nesting failure, breaking the nesting cycle, and preventing completion of breeding activity in a given number of nests, these results support the sea condition hypothesis since significant wave height in the year 2000 was significantly higher than in the years
1999 and 1998. The fact that there were significant differences between sites may be due to the different degree of effects on the three sampling sites by the same swell.

The deleterious effect of strong wind generating water turbulence and hence damaging the nests of fresh water fishes has been described previously (Goff 1985, 1986; Nack et al., 1993; Popiel et al., 1996). Goff (1985, 1986, and references therein) found that nest success was higher when total hours of strong wind was lower. Popiel et al. (1996) investigated the influence of several environmental factors on reproduction success in a lake fish species and found that only wind-generated turbulence was important. If the phenomenon of winds that physically disrupt nests is important for fish species inhabiting lakes, one can imagine the importance of effects that sea conditions may have on the viability of nests constructed in shallow inshore marine waters. Nest destruction in the case of the five-spotted wrasse is thus mainly the result of extreme weather conditions. In a few cases $(<2 \%)$, however, nest destruction can also be due to the action of sea urchins or some unknown predators (personal observation).

The number of abandoned nests was high. This relatively large percentage of abandoned nests can reflect the high percentage of nests that did not acquire eggs, and which were subsequently left by the male one or two days after the begining of construction, as observed previously in freshwater fishes (Mol, 1996).

Information concerning the effects of storms on the diverse fish faunas of coral reefs and in temperate seas mainly deals with the mortality and migration to deeper areas of fishes after the passage of major storms (Walsh, 1983; Harmelin-Vivien and Laboute, 1986; and references therein). Information on the adverse effects of wave action on nesting activity for marine fishes is scarce. Furthermore, though the effects of sea conditions have been studied little in other species, the observations presented here indicate that-at least for Symphodus roissali-wave action in the shallows may have devastating effects on nesting success. At the same time, sufficiently protracted periods of favourable sea conditions allow nests to survive the entire nesting cycle, and hence larval output tends to be concentrated within such periods. Further research is needed to determine whether settlement and recruit survival match this nesting pattern, and hence may be predictably coupled with periods of calm weather condition. 


\section{ACKNOWLEDGEMENTS}

I thank E. Macpherson for his advice and criticism, and T. García-Rubies and T. Alcoverro for insightful discussions during the preparation of the text. S. Mariani helped with the revision of the text and R. Sacks with the English version. I also thank I. Abreu for assistance with field work. This study was financially supported by a TDOC fellowship to N. R.

\section{REFERENCES}

Cushing, D.H. - 1969. The regularity of the spawning season of some fishes. J. Cons. Int. Expl. Mer., 33: 81-92.

Ebeling, A.W. and M.A. Hixon. - 1991. Tropical and temperate reef fishes: comparison of community structures. In: P. F. Sale (ed.), The Ecology of Fishes on Coral Reefs. pp. 509-563. Academic Press, San Diego.

García-Rubies, A. and E. Macpherson. - 1995. Substrate use and temporal pattern of recruitment in juvenile fishes of the Mediterranean littoral. Mar. Biol., 124: 35-42.

Goff, G.P. - 1985. Environmental influences on annual variation in nest success of smallmouth bass, Micropterus dolomieu, in Long Point Bay, Lake Erie. Env. Biol. Fish., 4: 303-307.

Goff, G.P. - 1986. Reproductive success of male smallmouth bass in Long Point Bay, Lake Erie. Trans. Amer. Fish. Soc., 115: 415-423.

Gordoa, A., B. Molí and N. Raventós. - 2000. Growth performance of four wrasse species on the north-western Mediterranean coast. Fish. Res., 45: 43-50.

Goulet, D. - 1995. Temporal patterns of reproduction in the Red Sea damselfish Amblyglyphidodon leucogaster. Bull. Mar. Sci., 57: 582-595.

Harmelin-Vivien, M.L. and P. Laboute. - 1986. Catastrophic impact of hurricanes on atoll outer reef slopes in the Tuamotus (French Polynesia). Coral Reefs, 5: 55-62.

Helas, T., P. Lejeune, C. Michel and J. Voss. - 1982. A propos de quelques poissons de la Méditerranée: Symphodus (Crenilabrus) roissali (Risso 1810). Rev. Franc. Aq., 9: 29-32.

Jennings, M.J. and D.P. Philipp. - 1994. Biotic and abiotic factors affecting survival of early life history intervals of a streamdwelling sunfish. Env. Biol. Fish, 39: 153-159.

Johannes, R.E. - 1978. Reproductive strategies of coastal marine fishes in the tropics. Env. Biol. Fish, 3: 65-84.

Lejeune, P. and J. Voss. - 1979a. A propos de quelques poissons de la Méditerranée: Symphodus (Crenilabrus) melanocercus (Risso, 1810). Revue Franc. Aq., 6: 30-32.

Lejeune, P. and J. Voss. - 1979b. A propos de quelques poissons de la Méditerranée: Symphodus (Crenilabrus) rostratus (Bloch, 1797). Revue Franc. Aq., 6: 55-57.

Lejeune, P. and J. Voss. - 1980. A propos de quelques poissons de la Méditerranée: Symphodus (Crenilabrus) cinereus (Bonaterre, 1788). Revue Franc. Aq., 7: 29-32.

Lejeune, P. - 1985. Le comportment sociaux des labrides mediterranéens. Cah. Ethol. Appl., 5: 1-208
Lucas, J.A. and D.J. Orth. - 1995. Factors affecting nesting success of smallmouth bass in a regulated Virginia stream. Trans. Amer. Fish. Soc., 124: 726-735.

Macpherson, E., A. García-Rubies and A. Gordoa. - 2000. Direct estimation of natural mortality rates for littoral marine fishes using population data from a marine reserve. Mar. Biol., 137: 1067-1076.

Mol, J.H. - 1996. Reproductive seasonality and nest-site differentation in three closely related armoured catfishes (Siluriformes: Callichthyidae). Env. Biol. Fish, 45: 363-381.

Nack, S.B., D. Bunnell, D.M. Green and J.L. Forney. - 1993. Spawning and nursery habitats of largemouth bass in the tidal Hudson River. Trans. Amer. Fish. Soc., 122: 208-216.

Noltie, D.B. and M.H.A. Keenleyside. - 1987. Breeding ecology, nest characteristics, and nest site selection of stream- and lakedwelling rock bass, Amblopites rupestris (Rafinesque). Can. J. Zool. 65: 379-390.

Popiel, S.A., A. Perez-Fuentetaja, D.J. McQueen and N.C. Collins. - 1996. Determinants of nesting success in the pumpkinseed (Lepomis gibbosus): a comparison of two populations under different risks from predation. Copeia, 649-656.

Quignard, D.P. and A. Pras. - 1986. Labridae. In: Whitehead, P.J.P., M.L. Bauchot, J.C. Hureau, J. Nielsen and E. Tortonese (eds.), Fishes of the North-eastern Atlantic and the Mediterranean, pp. 917-957. UNESCO, Paris.

Raventós, N. and E. Macpherson. - 2001. Planktonic larval duration and settlement marks on the otoliths of Mediterranean littoral fishes. Mar. Biol., 138: 1115-1120. doi: 10.1007/s002270000535

Robertson, D.R., C.W. Petersen and J.D. Brawn. - 1990. Lunar reproductive cycles of benthic-brooding reef-fishes: reflections of larval-biology or adult-biology? Ecol. Monogr., 60: 311-329.

Robertson, D.R. - 1991. The role of adult biology in the timing of spawning of tropical reef fishes. In: P.F. Sale (ed.), The Ecology of Fishes on Coral Reefs, pp. 356-386. Academic Press, San Diego.

Secor, D.H. - 2000. Spawning in the nick of time? Effect of adult demographics on spawning behaviour and recruitment in Chesapeake Bay striped bass. ICES J. Mar. Sci., 57: 403-411. doi: 10.1006/jmsc. 1999.0520

Van den Berghe, E.P. - 1990. Variable parental care in a labrid fish: how care might evolve. Ethology, 84: 319-333.

Walsh, W.J. - 1983. Stability of a coral reef fish community following a catastrophic storm. Coral Reefs, 2: 49-63.

Walsh, W.J. - 1987. Patterns of recruitment and spawning in Hawaiian reef fishes. Env. Biol. Fish, 18: 257-276.

Warner, R.R. and P. Lejeune. - 1985. Sex change limited by paternal care: a test using four Mediterranean labrid fishes, genus Symphodus. Mar. Biol., 87: 89-99.

Wernereus, F., C. Michel and J. Voss. - 1987. Introduction à l'étude de la sélection sexuelle chez Symphodus ocellatus (Förskal 1755 ) et $S$. melanocercus (Risso 1810), poissons labridés méditerranéens. Cah. Eth. Appl., 7: 19-38.

Whitehead, P.J.P., M.L. Bauchot, J.C. Hureau, J. Nielsen and E. Tortonese. - 1986 (eds.), Fishes of the Northeastern Atlantic and the Mediterranean, UNESCO, Paris.

Zika, U. - 1999. Factors affecting settlement and post-settlement processes in littoral marine fishes, focusing on Aidablennius sphynx. PhD thesis, Swiss Federal Institute of Technology, Zurich.

Scient. ed.: M. Harmelin-Vivien 